\title{
Immobilization of enzymes on heterofunctional epoxy supports
}

\author{
Cesar Mateo, Valeria Grazu, Jose M Palomo, Fernando Lopez-Gallego, Roberto Fernandez-Lafuente \& \\ Jose M Guisan
}

Departamento de Biocatálisis, Instituto de Catálisis, CSIC, Campus UAM, Cantoblanco, Madrid 28049, Spain. Correspondence should be addressed to R.F.-L. (rfl@icp.csic.es) or J.M.G. (jmguisan@icp.csic.es).

Published online 26 April 2007; doi:10.1038/nprot.2007.133

\begin{abstract}
Immobilization of enzymes and proteins on activated supports permits the simplification of the reactor design and may be used to improve some enzyme properties. In this sense, supports containing epoxy groups seem to be useful to generate very intense multipoint covalent attachment with different nucleophiles placed on the surface of enzyme molecules (e.g., amino, thiol, hydroxyl groups). However, the intermolecular reaction between epoxy groups and soluble enzymes is extremely slow. To solve this problem, we have designed "tailor-made" heterofunctional epoxy supports. Using these, immobilization of enzymes is performed via a two-step process: (i) an initial physical or chemical intermolecular interaction of the enzyme surface with the new functional groups introduced on the support surface and (ii) a subsequent intense intramolecular multipoint covalent reaction between the nucleophiles of the already immobilized enzyme and the epoxy groups of the supports. The first immobilization may involve different enzyme regions, which will be further rigidified by multipoint covalent attachment. The design of some heterofunctional epoxy supports and the performance of the immobilization protocols are described here. The whole protocol to have an immobilized and stabilized enzyme could take from 3 days to 1 week.
\end{abstract}

\section{INTRODUCTION}

Immobilization-stabilization of enzymes

The main application of enzyme immobilization is the industrial reuse of enzymes for many reaction cycles ${ }^{1-6}$. In addition, enzyme immobilization should always result in an increase in enzyme stability. The development of simple protocols for immobilization and stabilization of industrial enzymes is therefore a very exciting goal in enzyme biotechnology, because immobilized and highly stabilized enzyme preparations could be very useful for a massive implementation of sustainable chemical processes catalyzed by enzymes.

Multipoint covalent attachment is one of the most interesting approaches to link immobilization and stabilization of enzymes. Stabilization factors ranging between 100 and 1,000,000 have been reported $^{1-6}$. Theoretically, an enzyme molecule attached to a rigid support through many covalent linkages, and via very short spacer arms, should be highly stabilized, that is, the enzyme residues involved in the covalent immobilization should keep their relative positions unaltered during any conformational changes of the protein promoted by any distorting agent (heat, organic solvents, etc.). In this way, the intensity of these conformational changes should be strongly reduced. In fact, it should be similar to a multiintramolecular crosslinking, where the support acts as a rigid multicrosslinking agent. In this way, even if only $20-30 \%$ of the enzyme surface is involved in the immobilization on the support surface, the stabilization of the whole immobilized enzyme molecule may be very intense $\mathrm{e}^{7,8}$.

To take full advantage of this technique, immobilization needs to fulfill two requirements: (i) the reaction should proceed in such a way that the activity of the enzyme is not highly reduced, and (ii) a relatively high number of reactive groups in the enzyme should be involved in the reaction. It has been shown that different surface regions of the protein have different relevance for the enzyme stability ${ }^{9,10}$. An optimal immobilization-stabilization strategy should involve multipoint covalent immobilization through surface regions that are rich in residues able to react with activated supports as well as being relevant to enzyme stability. It is therefore useful to perform multipoint covalent attachment through each of the different regions of enzyme surfaces in order to develop the best stabilization strategy for a particular enzyme.

Immobilization of proteins on monofunctional epoxy supports At first glance, epoxy-activated supports are almost ideal matrices to perform a very easy immobilization-stabilization of proteins via multipoint covalent attachment ${ }^{11,12}$. Epoxy groups bear short spacer arms and may react with many nucleophilic groups present on the protein surface (e.g., Lys, Cys, His, Tyr) and, in a slower way, with carboxylic groups. Moreover, these groups may also react with carboxylic groups producing an ester bond, although this reaction proceeds in a much slower fashion ${ }^{11}$. In addition, epoxy groups are very stable, making it possible to perform long-term incubations of immobilized enzymes under alkaline conditions in order to get an intense multipoint covalent attachment (e.g., involving a number of Lys residues with a relatively high $\mathrm{pK}$ value $)^{13,14}$. Furthermore, a very intense multipoint covalent immobilization promotes only very mild chemical modifications of the protein surface (e.g., secondary amine, thioether, ether).

It has, however, been reported that soluble proteins are scarcely reactive with epoxy-activated supports even under slightly alkaline conditions ${ }^{15-18}$. At first glance, this extremely low intermolecular reactivity between epoxy groups and nucleophiles on the protein surface constitutes a serious drawback of monofunctional epoxy supports as supports for single enzyme immobilization protocols and for more interesting enzyme immobilization-stabilization protocols.

Multipoint covalent immobilization of proteins on heterofunctional epoxy supports

This very low intermolecular reactivity between epoxy supports and proteins does however open new exciting possibilities to 
rigidify each protein through different regions of its surface. By preparing different heterofunctional epoxy supports ${ }^{19-21}$, diverse two-step immobilization protocols can be developed. The overall steps of this procedure are

(i) Rapid physical or chemical fixation of protein on the support surface (through different regions of the protein surface) and

(ii) Promotion of intramolecular multipoint attachment between the epoxy groups of the support and the nucleophiles placed in the vicinity of the region of the protein participating in the first fixation.

Heterofunctional epoxy supports contain a low concentration of chemical moieties (easily introduced on a few epoxy groups) (Fig. 1a) able to promote the adsorption or attachment of the protein molecule to the support as well as a very high concentration of epoxy groups able to promote an intense additional multipoint covalent attachment between the protein and the support ${ }^{17}$.

As an exception, commercial hydrophobic epoxy supports do not need any kind of extrafunctionalization. At high ionic strength, adsorption through the external hydrophobic pockets of the proteins occurs, allowing covalent attachment between nucleophiles and epoxy groups ${ }^{15-18}$. In fact, this kind of two-step immobilization using hydrophobic supports has already been reported for many enzymes ${ }^{11,12}$. However, protocols for covalent immobilization of enzymes through epoxy groups at low ionic strength or on hydrophilic supports had not yet been reported until the proposal of heterofunctional epoxy supports ${ }^{19}$. Table 1 shows some examples of different chemical moieties able to promote a rapid physical or chemical binding (under very mild conditions) of proteins to heterofunctional hydrophobic or hydrophilic epoxy supports. Each chemical moiety promotes different interactions involving different regions of the protein surface.

Although long-term incubation of the already immobilized proteins under neutral $\mathrm{pH}$ may promote the formation of a few covalent linkages between the protein and the epoxy groups in the support $^{11,12}$, the highest intensity of multipoint covalent attachment is achieved via a long-term incubation under alkaline conditions because of the increase in the reactivity of nucleophiles (mainly Lys residues usually present on the protein surface) ${ }^{13,14,22}$ (Fig. 1b).

\section{Likely applications}

The use of several of these supports may permit the immobilization of a particular enzyme with different orientations, resulting in each preparation having very different activity/stability/selectivity. Examples of this approach include: immobilization of $\beta$-galactosidase (Aspergillus niger $)^{23}$, epoxyde hydrolase (A. niger $)^{24}$, glutaryl acylase $^{25}, \beta$-galactosidase (Thermus sp ${ }^{26}$ on different heterofunctional epoxy supports. In all the cases, different enzyme activity a
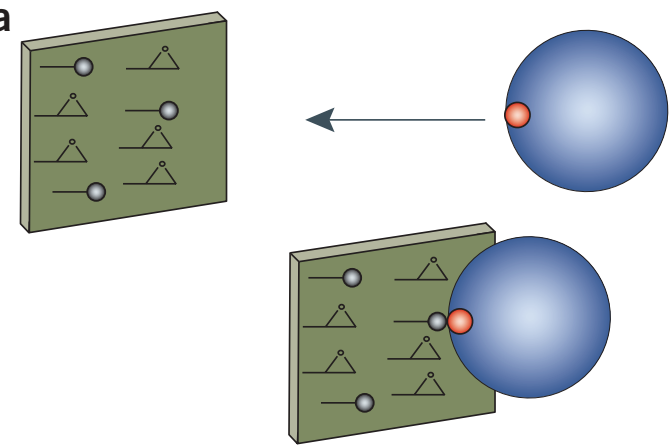

b

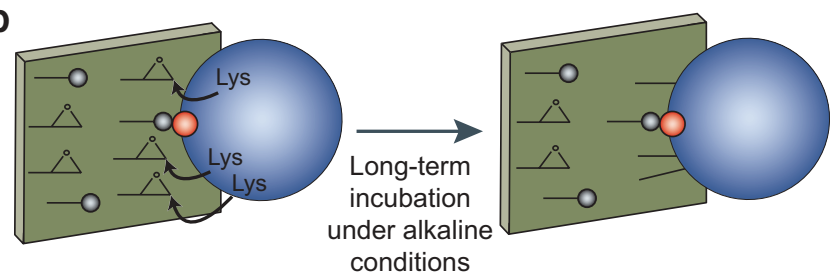

Figure 1 | Protein interactions on heterofunctional epoxy-supports. (a) Physical or chemical immobilization of proteins (blue). Groups in the protein able to interact with the groups in the support. Groups in the support able to promote a rapid physical or chemical fixation of the protein on the support surface. (b) Multipoint reaction of nucleophiles of immobilized proteins and epoxy groups.

recoveries and stabilities resulted from immobilization of the enzymes on different heterofunctional epoxy supports.

These supports permit immobilization under a very broad range of conditions; the only requirement is that the enzyme must become adsorbed on supports activated with the new groups ${ }^{19}$. Thus, immobilization may be performed at low ionic strength from $\mathrm{pH} 4$ to 10 by combining carboxy-epoxy or amino-epoxy supports. Boronate-epoxy ${ }^{19}$ or disulfide-epoxy ${ }^{20}$ have an even broader range of conditions under which they may be used.

Recently, it has been shown that the immobilization of enzymes that suffer significant conformational changes during catalysis (e.g., lipases, penicillin G acylase (PGA)) permits that the properties of these may be altered by involving different regions of the protein in the immobilization ${ }^{27-32}$. In this sense, heterofunctional supports enable the preparation of lipases having very different enantiospecificities $^{32}$.

When the protein to be immobilized (e.g., antibodies, proteases, amylases) needs to recognize very large substrates (other proteins, starch, etc.), the orientation of the immobilized enzyme regarding the support is a key point: only if the active center is exposed to the medium, the protein will be able to recognize these large

TABLE 1 | Different groups that may be used in the design of heterofunctional epoxy supports.

\begin{tabular}{ll}
\hline Group & Interaction \\
\hline $\begin{array}{l}\text { Hydrophobic supports } \\
-\mathrm{NH}_{3}^{+}\end{array}$ & $\begin{array}{l}\text { Hydrophobic pockets on the protein surface at very high ionic strength } \\
\text { Anionic exchange with protein regions that are rich in negative charges }\end{array}$ \\
$\begin{array}{l}\text { Highly reactive disulfide } \\
\text { groups-S-S-R }\end{array}$ & Formation of metal chelates with protein regions that are rich in His residues (e.g., poly-His-tagged proteins) \\
$-\mathrm{COO}^{-}$ & Thiol-disulfide exchange with Cys placed (or introduced in different regions of the protein surface) \\
\hline
\end{tabular}


substrates ${ }^{33-36}$. In these cases, the use of different supports immobilizing the protein via different regions may yield at least one immobilized protein preparation having the biological activity.

The use of epoxy supports bearing a second group able to specifically adsorb the target protein has proved to be a very useful tool for the one-step purification-immobilization-stabilization of proteins. Thus, tailor-made metal-chelate-epoxy supports (having an extremely low amount of metal-chelate groups) have been used to purify, immobilize and stabilize polyhistidine-tagged proteins (e.g., glutaryl acylase ${ }^{37}, \beta$-galactosidase from Thermus $\mathrm{sp}^{38}$ or peroxidas $\mathrm{s}^{39}$ ). Considering that the second group may be any kind of ligand, it may be expected that this technique may be applicable to many other cases (except using inhibitors, because that should yield an inhibited enzyme).

Another very exciting application of this two-step immobilization protocol may be the covalent immobilization of antibodies with the correct orientation (the Fab region opposite to the support surface) on a fully inert support surface. For example, the immobilization of antibodies on epoxy-metal-chelate supports afforded fully functional antibodies ${ }^{40}$. This kind of immobilized antibody (on porous supports or on magnetic nanoparticles) can be very useful to design immunoaffinity supports or immunobiosensors. After the two-step immobilization, epoxy groups on the support may be blocked with very high concentrations of, for example, glycine or cysteine, yielding a fully inert hydrophilic support surface.

Finally, disulfide-epoxy supports, which may not be able to immobilize many native proteins, are a powerful tool to get a site-directed rigidification of proteins. By coupling site-directed mutagenesis and this support, it is possible to prepare different mutants each having one superficial Cys residue. If each mutant has this Cys residue in different regions of the protein surface, it may be possible to get an immobilization via this Cys residue, and after that, rigidification of that area of the protein surface. This permits detection of the most relevant areas for enzyme stabilization against different inactivation agents $(\mathrm{T}$, drastic $\mathrm{pH}$ values, solvents, etc.). Moreover, this may permit to modulate the properties of enzymes like PGA or lipases. In our laboratory, we have got some very nice supports and experiments are ongoing to improve even that.

\section{MATERIALS}

\section{REAGENTS}

-Epoxy Sepabeads (EC-EP-Sepabeads; Resindion SRL, Mitsubishi Chemical Corporation) (ethylenediamine (EDA)-epoxy supports (EES))

- Eupergit C or 250 (Degussa, Röhm GmbH \& Co. KG) (EES and thiol-epoxy supports (TES))

- EDA (Sigma Chemical Company) (EES)

-! CAUTION Corrosive, flammable and harmful in contact with skin and if swallowed. Working with gloves and in a fume hood is recommended .

- Amino-Support modification solution: $0.3 \mathrm{M}$ ethylenediamine in distilled water at $\mathrm{pH} 8.5$ and $25{ }^{\circ} \mathrm{C}$ (adjusted with $1 \mathrm{M} \mathrm{HCl}$ ) (EES) $\triangle$ CRITICAL To prevent the oxidation of the ethylenediamine, when the $\mathrm{pH}$ is adjusted to 8.5 by adding $\mathrm{HCl}$, the temperature should not exceed $30^{\circ} \mathrm{C}$

-Washing solution 1: $1 \mathrm{M} \mathrm{NaCl} / 100 \mathrm{mM}$ sodium hydrogen carbonate at pH 8.5 (EES)

-Washing solution 2: $1 \mathrm{M} \mathrm{NaCl} / 100 \mathrm{mM}$ sodium acetate at pH 5.0 (EES)

- Protein immobilization buffer 1: $5 \mathrm{mM}$ sodium dihydrogen phosphate buffer at pH 7.0 (adjusted with $5 \mathrm{M} \mathrm{NaOH}$ ) (EES)

- Protein desorption solution 1: $1.5 \mathrm{M}$ sodium dihydrogen phosphate at $\mathrm{pH}$ 7.0 (adjusted with $5 \mathrm{M} \mathrm{NaOH}$ ) (EES)

- Multipoint covalent attachment incubation buffer: $0.1 \mathrm{M}$ sodium hydrogen carbonate at pH 8.5 or 10 (adjusted with $5 \mathrm{M} \mathrm{NaOH}$ ) (EES)

- Blocking solution: $3 \mathrm{M}$ glycine at pH 8.5 (EES)

- Mercaptoethanol was from Sigma Chemical Company (EES) ! CAUTION

Harmful if swallowed. Toxic in contact with skin. Causes burns. Working in a fume hood and with protective gloves is recommended.

- Blocking solution b: $1 \mathrm{M}$ mercaptoethanol in $50 \mathrm{mM}$ sodium dihydrogen phosphate $\mathrm{pH} 8.5$ (EES)

- Epoxy Sepabeads (FP-EP-Sepabeads) from Resindion SRL (Mitsubishi Chemical Corporation) (TES)

- Sodium sulfide was from Sigma Chemical Co. (TES) ! CAUTION Causes burns, and when in contact with acids liberates toxic gas. Working in a fume hood and using protective clothing is recommended.

-Thiol-Support modification solution: $50 \mathrm{mM}$ sodium hydrogen carbonate at pH 8.5 containing $1 \mathrm{mM}$ sodium sulfide at $25^{\circ} \mathrm{C}$ (TES)

$\cdot 2,2^{\prime}$-dipyridyl disulfide(2-PDS) (this compound is also named 2,2' -

dithiodipyridine) (Sigma Chemical Co.) (TES) ! CAUTION Irritating to eyes, respiratory system and skin. Wear protective clothing and gloves.

- Thiol determination buffer: $0.1 \mathrm{M}$ sodium dihydrogen phosphate (adjusted with $5 \mathrm{M} \mathrm{NaOH}$ at $\mathrm{pH} 8.0$ ) containing $1.5 \mathrm{mM}$ 2-PDS (TES)

- Thiol activating solution: $60 \%$ acetone $/ 40 \%(\mathrm{v} / \mathrm{v}) 50 \mathrm{mM}$ sodium hydrogen carbonate containing $0.2 \mathrm{M}$ 2-PDS (TES)

- Ethylene diamine tetraacetic acid (Sigma Chemical Co.) (TES)
-Washing solution 3: $60 \%$ acetone $/ 40 \%$ water (v/v) (TES)

-Washing solution 4: $1 \mathrm{mM}$ ethylene diamine tetraacetic acid dissolved in water (TES)

-Washing solution 5: $5 \mathrm{mM}$ sodium dihydrogen phosphate $\mathrm{pH} 7$ (adjusted with $5 \mathrm{M} \mathrm{NaOH}$ ) (TES)

-Washing solution 6: 0.2 M sodium acetate at pH 5.0 (TES)

- D,L-Dithiothreitol (DTT) (Sigma Chemical Co.) (TES) ! CAUTION Harmful if swallowed. Irritating to eyes, respiratory system and skin. Wear suitable protective clothing.

- $N$-succinimidyl 3-(2-pyridyldithio)propionate (SPDP) (Sigma Chemical Co.) (TES)

- Chemical thiolation solution: $25 \mathrm{mM}$ SPDP in ethanol (TES)

- Protein disulfide reducing solution: $500 \mathrm{mM}$ DTT in $0.1 \mathrm{M}$ sodium acetate pH 4.5 (TES)

- Protein elution solution: $50 \mathrm{mM}$ sodium dihydrogen phosphate containing $400 \mathrm{mM}$ DTT (final pH value is pH 8.0 adjusted with $5 \mathrm{M} \mathrm{NaOH}$ ) (TES)

- Multipoint covalent attachment incubation buffer: $0.1 \mathrm{M}$ sodium hydrogen

carbonate at pH 8.5 or 10 (adjusted with $5 \mathrm{M} \mathrm{NaOH}$ ) (TES)

- Blocking solution: $3 \mathrm{M}$ glycine at $\mathrm{pH} 8.5$ (TES)

-PD-10 columns (Sephadex G-25) (Pharmacia BTG-LKB) (TES)

EQUIPMENT

- Magnetic bars

- Sintered glass filter

-Vacuum filtering systems: to recover the supports and immobilized enzymes, these systems are simpler than centrifuges

$\cdot \mathrm{pH}$ stat

- Micropipettes to take samples

- Fume hood. Thiol compounds smell very strongly

REAGENT SETUP

Protein immobilization buffer $210 \mathrm{mM}$ sodium dihydrogen phosphate buffer at pH 7.0 (adjusted with $5 \mathrm{M} \mathrm{NaOH}$ ). Low concentrations (upto $10 \mathrm{mM}$ ) of protein stabilizers could be added to this buffer as long as they did not present primary amino groups or thiol groups (TES).

\section{EQUIPMENT SETUP}

Stirring systems The use of suspensions makes the use of mild stirring systems in order to have a homogenous suspension when taking samples necessary. This may be, for example, magnetic stirring, mechanical stirring with helix, orbital stirring or shakers. $\triangle$ CRITICAL Using heterogeneous suspensions, an adequate stirring system must be used in most of the steps (in activation of the support, immobilization of the enzymes or enzyme activity determination); however, this may not be used when the enzyme has been already immobilized and we only intend a more intense multipoint covalent attachment. 


\section{PROCEDURE}

\section{Preparation of supports}

1) Prepare the supports using by following the steps in options A, B and C, respectively. The moieties introduced in the support may be almost any molecule able to react with the epoxy groups and permit the adsorption of the target protein. To favor multipoint covalent attachment, always introduce the minimum amount of these groups to achieve the adsorption of our target protein in a reasonable time. Option A describes the preparation of EDA-epoxy, EDA-mercaptoethanol and EDA-supports; option B describes the preparation of thiol-epoxy and thiol-glycine supports; and option C describes the preparation of disulfide-epoxy and disulfide-glycine supports.

\section{(A) EDA-epoxy, EDA-mercaptoethanol and EDA supports}

(i) Wash $10 \mathrm{~g}$ of EP-Sepabeads or Eupergit C (five times with 10 volumes of deionized water).

(ii) Incubate the washed supports in $100 \mathrm{ml}$ of amino support modification solution at $25{ }^{\circ} \mathrm{C}$ under gentle stirring for $1 \mathrm{~h}$ (modification of around $20 \%$ of the epoxy groups is achieved). If the target enzyme does not become adsorbed on this low-activated support, the degree of modification of the epoxy groups in the support may be increased by longer incubation time with the amino support modification solution.

(iii) To modify all epoxy groups with EDA (EDA-support), increase the $\mathrm{pH}$ of the amino support modification solution to $\mathrm{pH} 10$ and allow the reaction to proceed for $24 \mathrm{~h}$.

(iv) Filter the EDA-epoxy supports and EDA-support on a sintered glass filter and wash thoroughly with washing solutions 1 and 2, and finally with distilled water. Eliminate the interparticle water by vacuum filtering. At this stage, the quantification of EDA groups introduced on the support may be performed by titrating the amino groups in the support by using a pH stat. Considering that the $p \mathrm{~K}_{\mathrm{a}}$ of these groups is around 7 for the primary and around 10 for the secondary amine, a titration with $10 \mathrm{mM} \mathrm{NaOH}$ from pH 4.8 to 8.8 will determine the concentration of the first group. It is recommended that $1.5 \mathrm{M}$ of $\mathrm{KCl}$ be added to the medium ${ }^{41}$.

(v) The remaining epoxy groups can be blocked with mercaptoethanol by incubation with the blocking solution 2 for 14-18 $\mathrm{h}$ to avoid reaction of the enzyme with the epoxy groups. EDA-mercaptoethanol-blocked supports should then be washed with washing solutions 1 and 2 and distilled water. This support may be used as a reference to check if the target protein becomes adsorbed on this support.

(vi) Store the wet (with pores full of water) EDA-epoxy supports at $4^{\circ} \mathrm{C}$. The adsorption and covalent immobilization properties remain almost unaltered after 1 month.

\section{(B) Thiol-epoxy and thiol-glycine supports}

(i) Wash $10 \mathrm{~g}$ of EP-Sepabeads or Eupergit $\mathrm{C}$ with deionized water.

(ii) Incubate the washed supports in $400 \mathrm{ml}$ of thiol support modification solution at $25{ }^{\circ} \mathrm{C}$ under gentle stirring for $5 \mathrm{~h}$.

(iii) Filter the thiol-epoxy supports on a sintered glass filter and thoroughly wash with washing solutions 1, 2 and 5 . Eliminate the interparticle water by vacuum filtering.

(iv) The thiol-epoxy supports can be stored at $4{ }^{\circ} \mathrm{C}$ (supports may be stored for a maximum of 1 week). To store these supports, wash them with washing solution 6 .

(v) To determine the amount of thiol groups introduced in the support, incubate $0.5 \mathrm{~g}$ of the thiol containing supports with $20 \mathrm{ml}$ of thiol determination buffer at $25^{\circ} \mathrm{C}$ under gentle stirring for $1 \mathrm{~h}$. Take a sample of the supernatant and determine the amount of pyridine-2-thione released from the support by measuring the absorbance of the supernatant at $343 \mathrm{~nm}$. The molar extinction coefficient of pyridine-2-thione ${ }^{42}$ is $8.02 \times 10^{3} \mathrm{M}^{-1} \mathrm{~cm}^{-1}$. The concentration of the thiol groups present on the support can be calculated using the following equation:

$$
\mu \text { mol thiol per } \mathrm{g} \text { of support }=\left(A_{343} \times V_{\text {total }} \times \text { dilution factor }\right) /(8.02 \times \mathrm{g} \text { of support })
$$

$V_{\text {total }}=20 \mathrm{ml}, \mathrm{g}$ of support $=0.5 \mathrm{~g}$. The basic reaction scheme of this titration is outlined in Figure 2 . The thiol groups of the support react forming a 2-pyridyl disulfide. Thereby, a 2-pyridyl thiol is produced in equimolecular amount to the reactive thiol groups on the support. The 2-pyridyl thiol is stabilized by its tautomeric thione form, which serves as chromophoric reporter as it strongly absorbs at $343 \mathrm{~nm}$. Owing to this stabilization, the position of equilibrium favors the products, and the reaction occurs quantitatively ${ }^{43-45}$.

(vi) To prepare a support where the attachment proceeds only via the thiol group, the remaining epoxy groups can be blocked with glycine by incubation with the blocking solution for $14-18 \mathrm{~h}$ to leave the thiol moieties as the only reactive group (thiol-glycine-blocked supports). The thiol-glycine-blocked supports should then be washed with washing solutions 1, 2 and 5 and vacuum-dried. This support may be used in order to check if thiol-disulfide exchange is the first step of the enzyme immobilization, and to have a protein immobilized but not rigidificated to be used as reference.

- PAUSE POINT Thiol-glycine supports can be stored at $4{ }^{\circ} \mathrm{C}$ for a maximum of 1 week. In general, thiol groups are not very stable and the stability decreases with the concentration. It may be convenient to check if the thiol groups are still reactive if the enzymes or supports have been stored for more than 2-3 days.

\section{(C) Disulfide-epoxy and disulfide-glycine supports}

(i) Prepare thiol-epoxy or thiol-glycine supports as described in option B. 
(ii) To activate the thiol group, incubate $10 \mathrm{~g}$ of thiol supports in 100 $\mathrm{ml}$ of the thiol-activating solution for $1 \mathrm{~h}$ at $25^{\circ} \mathrm{C}$.

$\triangle$ CRITICAL STEP The control of the modification of epoxide is critical, as too low will result in a very low immobilization and too high can hinder the multipoint covalent attachment. In some cases, the disulfide group may be in the protein. In this case, thiol supports could be directly used in immobilization.

\section{Immobilization of proteins} in the support.

\section{(A) On EDA-epoxy supports} hinder the multipoint covalent attachment.

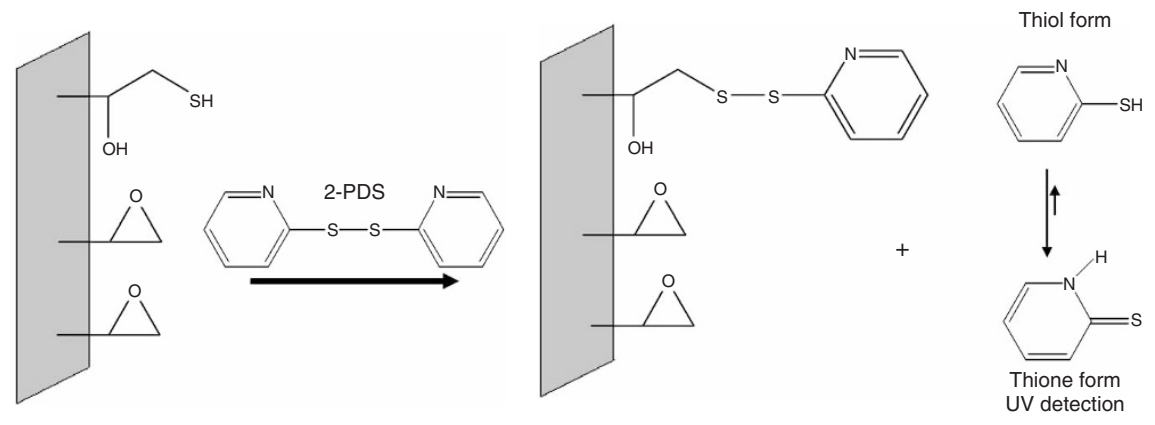

Figure 2 | Determination of the thiol groups in the support by thiol exchange between 2-PDS and thiol groups on the support.

(iii) Wash the thiol-reactive (epoxy or glycine) supports with washing solutions 3, 4 and 5 (approximately five times with each washing solution, each wash having a volume five times that of the support).

PAUSE POINT The thiol-reactive supports can be stored at $4{ }^{\circ} \mathrm{C}$ for 1 month.

2| Immobilize the proteins on EDA-epoxy, disulfide or thiol-epoxy supports by performing the steps in options A, B and C, respectively. In these methods, it is necessary to first determine whether the support is able to immobilize the target protein and then to optimize the conditions for this reaction. For EDA-epoxy supports, for example, the pH should be adjusted to conditions where the target protein is adsorbed. The standard protein immobilization buffer 1 should, however, be valid for around $70 \%$ of proteins at $\mathrm{pH}$ 7. Immobilization on disulfide-epoxy and thiol-epoxy supports is via thiol-disulfide exchange and therefore only proteins bearing exposed thiol groups can be immobilized on the support. Immobilization on thiol-epoxy supports is possible only when the protein has been chemically modified to introduce a disulfide group on its surface. $\triangle$ CRITICAL STEP Suitable references must be used to ensure that the immobilization is really due to the groups introduced

(i) Feasibility of the support to immobilize the target protein: dissolve the proteins in $90 \mathrm{ml}$ of protein immobilization buffer 1 . Add $7 \mathrm{~g}$ of EDA support (without epoxy groups) to the protein solution and stir this immobilization suspension gently. To this first approximation, $1 \mathrm{mg}$ of protein per $\mathrm{g}$ of support may be enough.

$\triangle$ CRITICAL STEP It is necessary to be sure that the enzyme becomes adsorbed on the support; otherwise, immobilization will be too slow. However, although the use of supports having many amino groups can accelerate the adsorption, it will

(ii) Periodically take samples of the supernatants and analyze for enzyme activity (Fig. 3; for an example using $\beta$-galactosidase, see Box 1). If the enzyme was adsorbed on the EDA-support, go to Step 2A(ix). If no adsorption of the protein was observed on the support, go to Step $2 \mathrm{~A}$ (iii).

(iii) Prepare immobilization buffer 1 at $\mathrm{pH}$ values from 5 to 9.

(iv) Dissolve the proteins in immobilization buffer 1 of different $\mathrm{pH}$ values.

(v) Add $7 \mathrm{~g}$ of EDA-support to the different protein solutions at the different $\mathrm{pH}$ values and stir these immobilization suspensions gently.

(vi) Periodically, take samples of the supernatants and analyze for enzyme activity. Choose the milder pH value for enzyme stability where the enzyme becomes adsorbed on the EDA-support and continue with the next section.

(vii) Immobilization on EDA-epoxy supports: add $7 \mathrm{~g}$ of EDA-epoxy support to $90 \mathrm{ml}$ of the protein solution at the $\mathrm{pH}$ value where the target enzyme becomes adsorbed on the EDA-support, and stir this immobilization suspension gently. Incubate a solution of enzyme under the same conditions as a reference.

(viii) Periodically, take samples of the supernatants and the reference, and analyze these for enzyme activity. If the enzyme becomes adsorbed on the support, go to Step $2 \mathrm{~A}(\mathrm{xi})$. If there is no significant immobilization after $5 \mathrm{~h}$, assume that the amount of cationic groups on the support is not enough to adsorb the target enzyme and go to Step $2 \mathrm{~A}$ (ix).

(ix) Prepare new EDA-epoxy supports, this time using longer reaction times with the amino support modification solution in order to increase the amount of EDA groups introduced in the support. Try modifications of 30, 40 and $50 \%$ of the epoxy groups (remember that although higher modification may permit adsorption, it will also result in decreased rate for the subsequent covalent reaction).

(x) Choose the EDA-epoxy support with the lowest concentration of EDA groups able to immobilize the protein.

(xi) Take $10 \mathrm{ml}$ of the chosen immobilization suspension; wash with washing solution 5 to eliminate all the proteins not bound to the support and dry under vacuum filter. 


\section{BOX 1 | EXAMPLE 1. IMMOBILIZATION OF $\beta$-GALACTOSIDASE FROM Aspergillus oryzae ON AMINO-EPOXIDE SUPPORTS}

\section{Materials:}

- $\beta$-Galactosidase was from A. oryzae (grade XI) and o-nitro-phenyl- $\beta$-o-galactopyranoside (o-NPG) was from Sigma Chemical Company.

- Activity solution was $10 \mathrm{mM} o-\mathrm{NPG}$ at $25^{\circ} \mathrm{C}$ in $0.1 \mathrm{M}$ sodium acetate $\mathrm{pH} 4.5$.

- UV spectrometer (stirring system is required for measuring immobilized enzymes).

\section{Procedure:}

To measure the enzyme activity, a sample of $100 \mu$ l of enzyme solutions or suspensions was added to a cell $(1 \mathrm{~cm} \times 1 \mathrm{~cm})$ containing $2.5 \mathrm{ml}$ of activity solution.

Enzyme activity was assayed by monitoring the increase in the absorbance at $405 \mathrm{~nm}$ caused by the release of $o$-nitrophenol under that conditions.

The commercial powder ( $\beta$-galactosidase, $8 \mathrm{IU} \mathrm{mg}^{-1}$ ) was dissolved at $2.5 \mathrm{mg} \mathrm{ml}^{-1}$ in the immobilization buffer and centrifuged at 2,400g to eliminate the insoluble fraction.

Samples of $20 \mathrm{ml}$ of this solution were added to $2 \mathrm{~g}$ of amino-epoxy-Eupergit containing different amounts of amino groups (from not aminated to fully aminated) under mild stirring.

$1 \mathrm{ml}$ samples of the supernatant and the suspensions were taken after 1, 3, 8 and $24 \mathrm{~h}$ to check the enzyme activities. From the results, the adsorption rate may be determined (Fig. $\mathbf{3}$ ).

$\triangle$ CRITICAL STEP To take samples of immobilized enzymes, it is necessary to use cut tips in the pipettes and use a vigorous stirring to ensure full dispersion.

To check the covalent binding, the enzyme suspensions were washed with protein immobilization buffer and vacuum-dried. Then, $50 \mathrm{mg}$ of this preparations was resuspended in desorption solution 1 to check the covalent attachment. This will show the covalent immobilization rate (Fig. 3 ).

\section{Results:}

Highly modified supports rapidly adsorbed the protein while covalent attachment was very slow. Thus, the highest covalent immobilization (that is influence by the rate of adsorption and the rate of epoxy-enzyme reaction) was achieved with a moderate concentration of EDA modification (around $20 \%$ of the epoxy groups of Eupergit C modified with EDA). This permitted a moderately rapid adsorption of the protein (in $3 \mathrm{~h}$ ) and a rapid covalent immobilization of the adsorbed proteins.

(xii) Add $0.7 \mathrm{~g}$ sample of the support with the immobilized proteins to $9 \mathrm{ml}$ of protein desorption solution 1.

(xiii) Stir this suspension gently for $30 \mathrm{~min}$.

(xiv) Determine the activity or the protein concentration in the supernatant. If the EDA-support released all the proteins whereas the EDA-reactive epoxy did not release any protein at all, this implies that covalent immobilization has occurred. If some protein was still released, longer enzyme-support incubation may be necessary to get the covalent immobilization.

$(x v)$ When there is no desorption of proteins in Step $2 A(x i v)$, the covalent immobilization is considered complete; wash the insoluble derivatives with washing solution 5 and distilled water (approximately five times with 5 volumes of each solution).

(B) On disulfide-epoxy supports

(i) Feasibility of the support to immobilize the target protein: dissolve the enzyme in $80 \mathrm{ml}$ of immobilization buffer 2. Protein stabilizers can be added to this buffer as long as they do not present any primary amino or thiol groups. $\triangle$ CRITICAL STEP Only some few proteins have free superficial Cys; thus, only if the enzyme may be immobilized in disulfide support, these supports will be valid for the natural enzyme.

(ii) Add $7 \mathrm{~g}$ of thiol-reactive glycine supports to the solution and stir this immobilization suspension gently at $25^{\circ} \mathrm{C}$.

(iii) Periodically, take samples of the supernatants and analyze them for enzyme activity. If the enzyme was immobilized on the thiol-reactive glycine, go to Step $2 \mathrm{~B}$ (xii). If immobilization of the protein on the support was not observed after $3 \mathrm{~h}$, this implies that the protein does not have exposed reactive thiol groups. In this case, sulfydryl groups need to be generated from reduction of indigenous disulfides (go to Step 2B(iv)) or created via site-directed mutagenesis or via controlled chemical modification (go to Step $2 \mathrm{C}$ (iv). Both procedures would need to be focused on the protein surface ${ }^{21,45}$.

(iv) Generation of sulfydryl groups by reduction of indigenous disulfides (an example of this, using $\beta$-galactosidase,

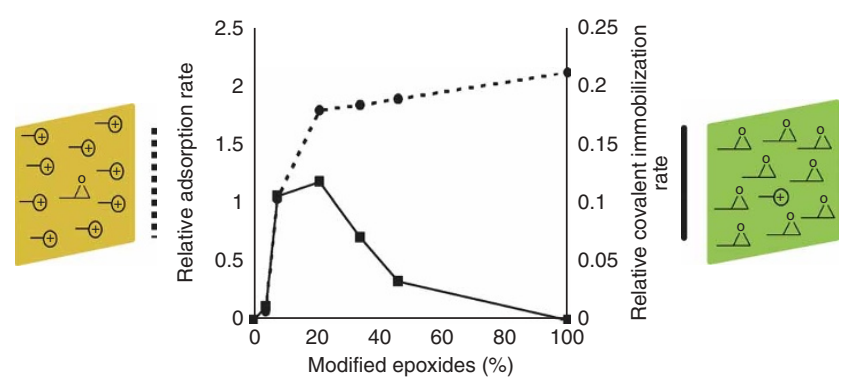

Figure 3 | Effect of the amination degree on the rates of ionic exchange and covalent attachment. 


\section{BOX 2 | AN EXAMPLE OF PROTEIN THAT NEEDS DISULFIDE REDUCTION FOR ITS IMMOBILIZATION ON DISULFIDE-EPOXIDE SUPPORTS: IMMOBILIZATION OF $\beta$-GALACTOSIDASE FROM $K$. lactis}

\section{Materials:}

$\beta$-Galactosidase from K. lactis (Maxilact LX 5000), supplied by Gist-Brocades. 0 -Nitro-phenyl- $\beta$-D-galactopyranoside (o-NPG) was from Sigma Chemical Company.

Activity solution was $30 \mathrm{mM}$ (o-NPG) at $25^{\circ} \mathrm{C}$ in $20 \mathrm{mM}$ potassium phosphate $/ 100 \mathrm{mM} \mathrm{KCl} / 2 \mathrm{mM} \mathrm{MgCl} 2 \mathrm{pH} 7$.

\section{Procedure:}

To measure the enzyme activity, a sample of $100 \mu \mathrm{l}$ of enzyme solutions or suspensions was added to a cell $(1 \mathrm{~cm} \times 1 \mathrm{~cm}) \mathrm{containing} 2.5 \mathrm{ml}$ of activity solution. To measure immobilized enzymes, a stirring system is necessary. One unit of enzyme (IU) was defined as the amount of enzyme catalyzing the hydrolysis of $1 \mu \mathrm{mol}$ of $o-\mathrm{NPG}$ per minute under the specified conditions.

$\triangle$ CRITICAL STEP To take samples of immobilized enzymes, it is necessary to use cut tips in the pipettes and use a vigorous stirring to ensure full dispersion.

Feasibility of the immobilization on disulfide-epoxide supports of Maxilact: $10 \mathrm{~g}$ of disulfide-glycine supports is added to $100 \mathrm{ml}$ of Maxilact $\left(2 \mathrm{mg} \mathrm{ml}^{-1}\right)$ in $50 \mathrm{mM}$ potassium phosphate and $2 \mathrm{mM} \mathrm{MgCl}_{2}$ at pH 7.0. After $6 \mathrm{~h}$ of incubation, no significant percentage of the enzyme had been immobilized. It has been previously shown that the reduction of $\beta$-galactosidase from $K$. lactis is a way of generating free reactive thiols as it improves the immobilization yield onto thiol-reactive adsorbents ${ }^{40}$.

Reduction of thiol groups: prepare an enzyme solution containing $30 \mathrm{mg} \mathrm{ml}^{-1}$ in $0.1 \mathrm{M}_{\text {potassium phosphate buffer and } 2 \mathrm{mM} \mathrm{MgCl}}$ at $\mathrm{pH} 7.0$ and add protein disulfide reducing solution to a final concentration of $25 \mathrm{mM}$, that is $50 \mu \mathrm{l}$ per ml of protein solution.

Allow the reaction to proceed for $30 \mathrm{~min}$ at $25^{\circ} \mathrm{C}$. Then, by dialysis or gel filtration eliminate the excess of reactive. Go to Step $2 \mathrm{~B}(\mathrm{xi})$.

is described in Box 2). Prepare a protein solution at a concentration of 1-20 $\mathrm{mg} \mathrm{ml}^{-1}$ in $50 \mathrm{mM}$ sodium phosphate $\mathrm{pH} 7.0$.

(v) Add protein disulfide reducing solution to a final concentration of $25 \mathrm{mM}$, that is $50 \mu \mathrm{l}$ per $\mathrm{ml}$ of protein solution.

(vi) Incubate the reaction mixture for 30 min at $25^{\circ} \mathrm{C}$.

(vii) Purify the reduced enzyme from the excess of DTT by gel filtration using $50 \mathrm{mM}$ sodium phosphate pH 7.0. The thiol-enzyme must be used immediately in immobilization to prevent sulfidryl oxidation (Fig. 4).

(viii) Immobilization on disulfide-epoxide supports: add $10 \mathrm{~g}$ of disulfide-epoxy or disulfide-glycine support to $90 \mathrm{ml}$ of reduced enzyme in $50 \mathrm{mM}$ sodium phosphate $\mathrm{pH}$ 7.0. Use a control with soluble enzyme and without support to determine the possible inactivating effect of incubating conditions $(\mathrm{pH}$, ionic strength, temperature) on the enzyme during the incubation period.

(ix) Periodically, take samples of the supernatant and suspension and analyze these for enzyme activity. $\triangle$ CRITICAL STEP To take samples of immobilized enzymes, it is necessary to use cut tips in the pipettes and use a vigorous stirring to ensure full dispersion.

(x) Take $10 \mathrm{ml}$ of immobilization suspension, filter it and wash with washing solution 5 to eliminate all the proteins not bound to the support, and dry under a vacuum filter.

(xi) Add $1 \mathrm{~g}$ (wet weight) of the support with the immobilized proteins to $9 \mathrm{ml}$ of protein elution solution. Stir this suspension gently for 30 min at $25^{\circ} \mathrm{C}$. Determine the activity or the protein concentration in the supernatant. If the thiol-reactive glycine support released all the proteins whereas the thiol-reactive-epoxy support
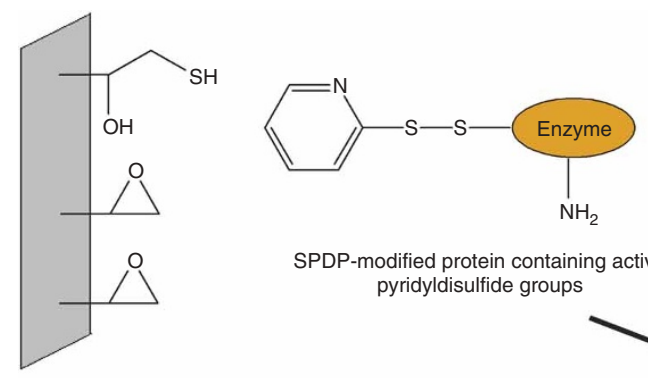

SPDP-modified protein containing active pyridyldisulfide groups
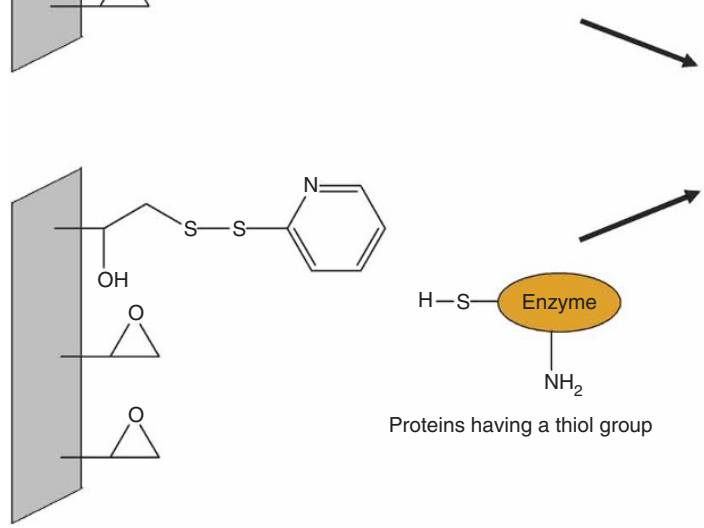

Proteins having a thiol group

Figure 4 | Immobilization of proteins (chemically modified or natural) on thiol or disulfide-epoxy supports. 


\title{
BOX 3 | AN EXAMPLE OF PROTEIN WITHOUT SUPERFICIAL THIOLS: IMMOBILIZATION OF PENICILLIN G ACYLASE FROM Escherichia coli ON THIOL-EPOXIDE SUPPORTS
}

\author{
Materials: \\ Pure penicillin $\mathrm{G}$ acylase (PGA) from E. coli (Antibioticos S.A. Leon, Spain) $\left(20 \mathrm{mg} \mathrm{ml}^{-1}\right)$, sodium penicillin $\mathrm{G}(\mathrm{PG})$ and $\mathrm{N}$-succinimidyl \\ 3-(2-pyridyldithio)propionate (SPDP).
}

\begin{abstract}
Procedure:
Measurement of the enzyme activity: Prepare $1 \%$ PG in sodium phosphate buffer at pH 8 and $25{ }^{\circ}$ C. Samples of $20 \mathrm{~mL}$ are placed in a thermostatized beaker and the $\mathrm{pH}$ is controlled by an automatic titrator, using $10 \mathrm{mM} \mathrm{NaOH}$. PGA (samples with an activity between 0.5 and $2 \mathrm{IU}$ ) is added and the activity of the enzyme is calculated from the $\mathrm{NaOH}$ consumption per minute.

Feasibility of the immobilization on disulfide-epoxide supports of natural PGA: $10 \mathrm{~g}$ of disulfide-glycine supports are added to $100 \mathrm{ml}$ PGA (2 mg $\mathrm{ml}^{-1}$ ) in $50 \mathrm{mM}$ sodium phosphate $\mathrm{pH}$ 7.0. After $6 \mathrm{~h}$, a significant immobilization of the enzyme could not be observed. This protein has no Cys residues; therefore, it is normal that the immobilization does not proceed ${ }^{46}$.

In case that the used protein was of unknown structure and/or sequence, before the chemical thiolation, it may be convenient to try the reduction of the protein to regenerate any existent thiol residue in the protein surface (Step 2B(iv)).

Chemical thiolation: Add to $100 \mathrm{ml}$ of PGA $\left(20 \mathrm{mg} \mathrm{ml}^{-1}\right)$ in $50 \mathrm{mM}$ sodium phosphate $\mathrm{pH} 7.0,9 \mathrm{ml}$ of chemical thiolation solution for $30 \mathrm{~min}$ at $25^{\circ} \mathrm{C}$ (this is a $1 / 1$ molar relation of SPDP with the enzyme molecules).

Then, by dialysis or gel filtration, eliminate the excess of reactive. The protein modified has already a reactive disulfide group.

Immobilization on thiol-epoxy supports: $10 \mathrm{~g}$ of thiol-epoxy or thiol-glycine supports is added to $100 \mathrm{ml}$ of modified PGA $\left(2 \mathrm{mg} \mathrm{ml}^{-1}\right)$ in $50 \mathrm{mM}$ sodium phosphate pH 7.0. After $12 \mathrm{~h}$, full immobilization of the enzyme was observed. Go to Step 2B(xi).

Immobilization on disulfide-epoxy supports. To get free thiol groups in the proteins support, go again to Step $2 \mathrm{~B}(\mathrm{x})$. Then go to Step $2 \mathrm{~B}(\mathrm{xi})$. In this case, full immobilization of the enzyme may be achieved after $12 \mathrm{~h}$.
\end{abstract}

did not release any protein at all, this implies that additional covalent immobilization have occurred between nucleophiles of the protein surface and epoxide groups of the support. If some protein is released, it is necessary to perform the enzyme-support reaction for longer times.

(xii) When the covalent immobilization is considered complete (that is, no release of protein to the supernatant is observed), the insoluble derivatives should be thoroughly washed with washing solution 5 and distilled water.

(C) On thiol-epoxy supports

(i) Chemical thiolation of the protein surface (an example is described in Box 3). Prepare a protein solution at a concentration of $1-20 \mathrm{mg} \mathrm{ml}^{-1}$ in $50 \mathrm{mM}$ sodium phosphate $\mathrm{pH} 7.0$ (ref. 46).

(ii) Then slowly add the chemical thiolation solution and incubate the reaction mixture at $25^{\circ} \mathrm{C}$ for 30 min under gentle stiring.

$\triangle$ CRITICAL STEP The introduction of just one disulfide on the enzyme surface is enough to permit the immobilization on a thiol-reactive support; thus, it is recommended to adjust the amount of SPDP to an equimolecular relation with the enzyme molecules to ensure a very mild modification of the protein, decreasing the negative effect of this modification on the enzyme activity.

(iii) Then, by dialysis or gel filtration, eliminate the reaction by-products. The SPDP-modified protein contains pyridildisulfide groups; therefore, it is not necessary to activate the thiol groups of the bifunctional supports with 2-PDS, and the protein could be immobilized directly to bifunctional supports containing thiol and epoxide groups (Fig. 4).

(iv) Immobilization on thiol-epoxide and thiol-glycine supports: add $10 \mathrm{~g}$ of thiol-epoxy supports to $100 \mathrm{ml}$ of SPDPmodified enzyme in $50 \mathrm{mM}$ sodium phosphate $\mathrm{pH}$ 7.0. Incubate a solution of enzyme under the same conditions as a reference.

(v) Periodically, take samples of the supernatant and suspension and analyze for enzyme activity (for around $12 \mathrm{~h}$ ). The non-immobilized protein should correspond to the percentage of enzyme molecules without disulfide groups.

$\triangle$ CRITICAL STEP To take samples of immobilized enzymes, it is necessary to use cut tips in the pipettes and use a vigorous stirring to ensure full dispersion.

(vi) Complete the immobilization by performing Steps 2B(viii)-(xii).

3| In some cases, these preparations are used directly in the blocking step. If higher stability is desired, multipoint covalent attachment is necessary.

Immobilized enzymes on supports bearing epoxy groups may become more stable if multipoint covalent attachment is achieved between the nucleophilic groups of the already covalently immobilized enzyme and the remaining epoxy groups in the support ${ }^{13,14}$. To achieve this, perform the following steps: (i) wash the immobilized preparations 5 times with 3 volumes of incubation buffer and resuspend in 3 volumes of that buffer. As this is a "pseudo-intramolecular" reaction, continuous stirring is not necessary. (ii) Periodically, take samples of the suspensions and analyze the enzyme activity. (iii) To stop the 
PROTOCOL

support-enzyme reaction (e.g., when the activity decreases and/or the stabilization was in the desired range), go to the next section.

$\triangle$ CRITICAL STEP To take samples of immobilized enzymes, it is necessary to use cut tips in the pipettes and use a vigorous stirring to ensure full dispersion.

\section{Blocking of the remaining epoxy groups on the support}

$\triangle$ CRITICAL STEP This step permits one to stop the enzyme-support reaction and also alter the physical properties of the support surface, critical in many cases for the enzyme stability. Moreover, it prevents substrates of the enzyme from reacting with the support during biocatalyst use.

4| Vacuum-dry the immobilized preparations, resuspend in 3 volumes of blocking solution and stir gently at $25^{\circ} \mathrm{C}$.

5| After $24 \mathrm{~h}$, wash the preparations with washing solutions 1 and 2 and distilled water. Store the immobilized preparations at $4{ }^{\circ} \mathrm{C}$. Never freeze the immobilized preparation, as this will result in physical destruction of the support.

\section{TIMING}

Immobilization on amino-epoxy supports

Synthesis of amino-epoxy supports: $4 \mathrm{~h}$

Synthesis of amino supports: $20-25 \mathrm{~h}$

Adsorption of proteins: $1-6 \mathrm{~h}$

Multipoint covalent attachment: $18-48 \mathrm{~h}$

Blocking of the remaining epoxy groups on the support: $20 \mathrm{~h}$

Immobilization on thiol or disulfide-epoxy supports

Synthesis of thiol-epoxy supports: $6 \mathrm{~h}$

Synthesis of thiol-glycine supports: $20-25 \mathrm{~h}$

Synthesis of thiol-reactive-epoxy and thiol-reactive-glycine supports: $7 \mathrm{~h}, 21-26 \mathrm{~h}$

Disulfide reduction of protein: $24 \mathrm{~h}$

Chemical thiolation of proteins: $24 \mathrm{~h}$

Immobilization of thiol-proteins or SPDP-modified proteins on disulfide or thiol-epoxy supports: 1-18 $\mathrm{h}$

Stabilization of immobilized enzymes by multipoint covalent attachment: $18-48 \mathrm{~h}$

Blocking of the remaining epoxy groups on the support: $20 \mathrm{~h}$

\section{ANTICIPATED RESULTS}

\section{Example 1: Immobilization of enzymes on different heterofunctional supports: effect of activity recovery.}

As discussed in INTRODUCTION, the immobilization of enzymes on different heterofunctional epoxy supports may permit the immobilization of the enzyme through different parts of the protein. In this way, it is possible that immobilization has very different effects on the enzyme activity when different supports are used.

Table 2 shows some of the most relevant results obtained in our laboratory.

Some enzymes are not significantly immobilized on certain supports ${ }^{19}$; for example, PGA from Escherichia coli is not immobilized on EDA-epoxy supports (this enzyme did not become adsorbed on mild anionic exchangers) ${ }^{47,48}$. The lack of external Cys on the enzyme means that the immobilization on the disulfide-epoxide support was very poor. This problem was solved by chemical thiolation of the enzyme, which enabled its immobilization on thiol-epoxy supports (Box 3 ). In other cases, although the enzymes are immobilized, the expressed activity is very different. For example, $\beta$-galactosidase from $A$. oryzae is fully inactivated when immobilized on conventional hydrophobic epoxy-supports, but retains almost full activity when immobilized on EDA-epoxy supports ${ }^{19}$. Similarly, epoxide hydrolase from $A$. niger retained only $30 \%$ of its activity when immobilized on

TABLE 2 | Effect of the type of epoxide support on the activity recovery after immobilization of different enzymes.

\begin{tabular}{|c|c|c|c|}
\hline Enzyme (reference) & Hydrophobic & EDA-epoxy & Disulfide-epoxy \\
\hline Lipase $(\text { C. rugosa })^{19}$ & 100 & 95 & $<5$ \\
\hline $\mathrm{PGA}(E . \text { coli })^{14}$ & 75 & $<5$ & $<5$ \\
\hline$\beta$-Galactosidase $(\text { A. oryzae })^{19,25}$ & 0 & 95 & $<5$ \\
\hline$\beta$-Galactosidase (E. coli) & ND & ND & 100 \\
\hline$\beta$-Galactosidase (Kluyveromices lactis) & ND & 15 & 100 \\
\hline Epoxide hydrolase $(A \text {. niger })^{24}$ & 30 & 95 & 5 \\
\hline
\end{tabular}

Immobilization was performed at $\mathrm{pH} 7.0$ and $4{ }^{\circ} \mathrm{C}$ under optimal concentration of sodium phosphate. ND, not determined. 
hydrophobic epoxy supports, whereas recovered activity was nearly $100 \%$ using EDA-epoxy supports ${ }^{24}$. $\beta$-Galactosidase from $E$. coli is an example where the enzyme has many exposed Cys residues. This permits the rapid immobilization on disulfideepoxy Eupergit. For the lipase from Candida rugosa, the highest activity recovery was obtained using the conventional hydrophobic-epoxy support ${ }^{19}$.

Example 2. Immobilization of enzymes on different heterofunctional supports: effect of the kind of support on the enzyme stabilization by multipoint covalent attachment. As discussed in INTRODUCTION, stabilization of enzymes by multipoint covalent or multisubunit attachment is a wellestablished technique, requiring a suitable system to permit intense support-enzyme interactions ${ }^{1-6}$. However, final results depend on different factors: (i) the area of the enzyme near the support must contain a relatively high number of groups able to react with the support; (ii) this area must be relevant for the enzyme stability; and (iii) in the case of multimeric enzymes, this orientation must be such that several protein subunits can be involved in the immobilization.

Immobilization of the proteins via different orientations may give very different final stability of the immobilized enzymes. For example, Figure 5 shows that when $\beta$-galactosidase from Thermus sp T2 is immobilized on any epoxy support, it is more stable than the soluble enzyme. However, when using conventional hydrophobic epoxy supports or EDA-epoxy supports, the stabilization is very poor; using boronate-epoxy or IDA-Me ${ }^{2+}$-epoxy supports, the stabilization factor becomes very significant ${ }^{26}$. Similarly, Figure 6 shows that glutaryl acylase immobilized on conventional hydrophobic-epoxy supports is much less stable than the enzyme immobilized on EDA-epoxy-supports ${ }^{25}$.

Figure 7 shows that epoxyde hydrolase from $A$. niger immobilized on EDA-epoxy supports is much more stable than the same enzyme immobilized on conventional hydrophobic supports ${ }^{22}$.

\section{Example 3: Immobilization of enzymes on different heterofunctional supports: effect on the enantiospecificity of lipases.}

It has been shown that the properties of lipases, owing to the peculiar mechanism of catalysis (involving dramatic conformational changes), may be strongly modulated by involving different regions of the enzyme in the immobilization ${ }^{27-30}$. Modified conformational changes of lipases produce lipase preparations yielding very different properties.

Lipases may be immobilized on commercial epoxy supports (having a hydrophobic matrix) even at low ionic strength. This is due to the fact that they can become adsorbed on the hydrophobic surface of the support via interfacial activation (even at low ionic strength). This particular feature of lipases has been used to immobilize, purify and hyperactivate lipases in just one step using supports like octyl-agarose ${ }^{49}$, but in this case it is a problem because it has been assessed that the partial modification of the support surface, even with hydrophilic groups like EDA or IDA, is not enough to prevent the interfacial adsorption. However, by adding a small concentration of detergents (e.g., $0.5 \%$ Triton X-100), adsorption via interfacial activation may be fully prevented ${ }^{29}$, and lipases will become adsorbed by the groups inserted in the matrix. Other possible problems using lipases is their tendency to form lipase-lipase dimers with altered properties; this is also solved using detergents ${ }^{50-52}$.

Therefore, considering that the use of different heterofunctional epoxy supports may result in the immobilization of lipases via different areas, different epoxy-heterofunctional supports were used to immobilize the lipase from Mucor miehei and the

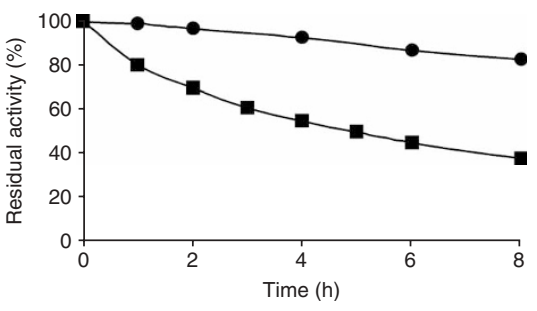

Figure 6 | Effect of the support on the thermal stability of immobilized glutaryl acylase ${ }^{25}$. Derivatives were immobilized at $\mathrm{pH} 7$ for $24 \mathrm{~h}$ and further incubated for $48 \mathrm{~h}$ at pH 10 and $25^{\circ} \mathrm{C}$ before blocking with $3 \mathrm{M}$ glycine. Inactivations were carried out at $45^{\circ} \mathrm{C}$ and $\mathrm{pH}$ 7.0. (Circles) Sepabeads-EDAepoxy; (squares) Sepabeads-epoxy.

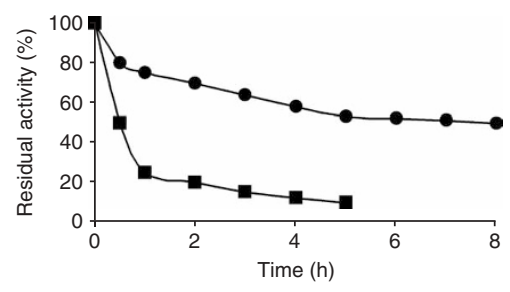

Figure 7 | Effect of the support on the thermal stability of immobilized epoxyde hydrolase from $A$. niger. Derivatives were immobilized at $\mathrm{pH} 7$ for $24 \mathrm{~h}$ and further incubated for $48 \mathrm{~h}$ at pH 10 and $25^{\circ} \mathrm{C}$ before blocking with $3 \mathrm{M}$ glycine. Inactivations were carried out at $50^{\circ} \mathrm{C}$ and $\mathrm{pH} 7.0$, (circles) Sepabeads-EDA-epoxy; (squares) Sepabeads-epoxy. 
PROTOCOL

TABLE 3 | Effect of the heterofunctional support on the enantio-specificity $(E)$ of the lipase from Mucor miehei32.

\begin{tabular}{|c|c|}
\hline Enzyme preparation & $E$-value \\
\hline IDA-epoxy & 60.0 \\
\hline EDA-epoxy & 1.2 \\
\hline IDA-Me ${ }^{2+}$-epoxy & 2.2 \\
\hline
\end{tabular}

The results show the $E$-value in the hydrolysis of $(R, S)$ 2-0-butyryl-2-phenylacetic acid at $\mathrm{pH} 7$ and $4^{\circ} \mathrm{C}$.

enantioselectivity of these preparations against \pm butyroyl-2 phenylacetic acid was studied ${ }^{32}$. Table 3 shows the different results obtained at 25 and $4^{\circ} \mathrm{C}$. While the enzyme immobilized on IDA-Me ${ }^{2+}$-epoxy or EDA-epoxy supports was hardly enantioselective, the enzyme immobilized on IDA-epoxy supports (adsorbed via cationic exchange), was highly enantioselective $(E=60)^{32}$.

COMPETING INTERESTS STATEMENT The authors declare no competing financial interests.

Published online at http://www.natureprotocols.com Reprints and permissions information is available online at http://npg.nature.com/ reprintsandpermissions

1. Bickerstaff, G.F. Immobilization of enzymes and cells. in Methods in Biotechnology 1st edn. (ed. Bickerstaff, G.), Humana Press, Totowa, NJ, USA (1997).

2. Chibata, I., Tosa, T. \& Sato, T. Biocatalysis: immobilized cells and enzymes. J. Mol. Catal. 37, 1-24 (1986).

3. Hartmeier, W. Immobilized biocatalysts-from simple to complex systems. TIBTECH 3, 149-153 (1985).

4. Katchalski-Katzir, E. Immobilized enzymes: learning from past successes and failures. TIBTECH 11, 471-478 (1993).

5. Gupta, M.N. Thermostabilization of proteins. Biotechnol. Appl. Biochem. 14, 1-11 (1991).

6. Klibanov, A.M. Stabilization of enzymes against thermal inactivation. Adv. Appl. Microb. 14, 1-11 (1982).

7. Pedroche, J. et al. Effect of the support and experimental conditions in the intensity of the multipoint covalent attachment of proteins on glyoxyl-agarose supports. Correlation between enzyme-support linkages and thermal stability. Enzyme Microb. Technol. 40, 1160-1166 (2007).

8. Mateo, C. et al. Some special features of glyoxyl supports to immobilize proteins. Enzyme Microb. Technol. 37, 456-462 (2005).

9. Mansfeld, J. \& Ulbrich-Hofmann, R. Site-specific and random immobilization of thermolysin-like proteases reflected in the thermal inactivation kinetics. Biotechnol. Appl. Biochem. 32, 189-195 (2000).

10. Mansfeld, J., Vriend, G., Van den Burg, B., Eijsink, V.G. \& Ulbrich-Hofmann, R. Probing the unfolding region in a thermolysin-like protease by site-specific immobilization. Biochemistry 38, 8240-8245 (1999).

11. Turkova, J. et al. Methacrylate gels with epoxide groups as supports for immobilization of enzymes in $\mathrm{pH}$ range 3-12. Biochim. Biophys. Acta (BBA)Enzymol. 524, 162-169 (1978).

12. Katchalski-Katzir, E. \& Kraemer, D.M. Eupergit $\AA$ C, a carrier for immobilization of enzymes of industrial potential. J. Mol. Catal. B Enzymatic 10, 157-176 (2000).

13. Mateo, C. et al. Epoxy Sepabeads: a novel epoxy support for stabilization of industrial enzymes via very intense multipoint covalent attachment. Biotechnol. Progr. 18, 629-634 (2002).

14. Mateo, C., Abian, 0., Fernandez-Lafuente, R. \& Guisan, J.M. Increase in conformational stability of enzymes immobilized on epoxy-activated supports by favoring additional multipoint covalent attachment. Enzyme Microb. Technol. 26, 509-515 (2000).

15. Wheatley, J.B. \& Schmidt, D.E. Salt induced immobilization of affinity ligands onto epoxide-activated supports. J. Chromatogr. A 849, 1-12 (1999).

16. Wheatley, J.B. \& Schmidt, D.E. Salt induced immobilization of proteins on a highperformance liquid chromatographic epoxide affinity support. J. Chromatogr. 644, 11-16 (1993).

17. Wheatley, J.B., Lyttle, M.H., Hocker, M.D. \& Schmidt, D.E. Jr. Salt-induced immobilizations of DNA oligonucleotides on an epoxide-activated highperformance liquid chromatographic affinity support. J. Chromatogr. A 726, 77-90 (1996).

18. Bauer-Arnaz, K. et al. Salt-induced immobilization of small affinity ligands on an epoxide activated affinity support. J. Chromatogr. A 803, 73-82 (1998).
19. Mateo, C., Fernández-Lorente, G., Abian, 0., Fernández-Lafuente, R. \& Guisán J.M. Multifunctional epoxy-supports: a new tool to improve the covalent immobilization of proteins. The promotion of physical adsorptions of proteins on the supports before their covalent linkage. Biomacromolecules 1, 739-745 (2000).

20. Mateo, C. et al. Epoxy-amino groups: a new tool for improved immobilization of proteins by the epoxy method. Biomacromolecules 4, 772-777 (2003).

21. Grazú, V. et al. A novel bifunctional epoxy/thiol-reactive support to immobilize thiol containing proteins by the epoxy chemistry. Biomacromolecules 4, 1495-1501 (2003).

22. Blanco, R.M., Calvete, J.J. \& Guisan, J.M. Immobilization-stabilization of enzymes. Variables that control the intensity of the trypsin (amine)-agarose (aldehyde) multi-point covalent attachment. Enzyme Microb. Technol. 11, 353-359 (1988).

23. Torres, R. et al. A novel heterofunctional epoxy-amino Sepabeads for a new enzyme immobilization protocol: immobilization-stabilization of beta-galactosidase from Aspergillus oryzae. Biotechnol. Progr. 19, 1056-1060 (2003)

24. Mateo, C., Archelas, A., Fernandez-Lafuente, R., Guisan, J.M. \& Furstoss, R. Enzymatic transformations. Immobilized $A$. niger epoxide hydrolase as a novel biocatalytic tool for repeated-batch hydrolytic kinetic resolution of epoxides. Org. Biomol. Chem. 1, 2739-2743 (2003).

25. López-Gallego, F. et al. Optimization of an industrial biocatalyst of glutaryl acylase. Stabilization of the enzyme by multipoint covalent attachment onto new amino-epoxy-sepabeads. J. Biotechnol. 111, 219-227 (2004).

26. Pessela, B.C.C. et al. Stabilization of a multimeric $\beta$-galactosidase from Thermus $s p$. strain $T 2$ by immobilization on novel hetero-functional epoxy supports plus aldehyde-dextran cross-linking. Biotechnol. Progr. 20, 388-392 (2004).

27. Fernández-Lorente, G. et al. Modulation of lipase properties in macro-aqueous systems by controlled enzyme immobilisation: enantioselective hydrolysis of a chiral ester by immobilised Pseudomonas lipase. Enzyme Microb. Technol. 28, 389-396 (2001).

28. Palomo, J.M., Fernandez-Lorente, G., Mateo, C., Fernandez-Lafuente, R. \& Guisan J.M. Modulation of the enantioselectivity of lipases via controlled immobilization and medium engineering: hydrolytic resolution of mandelic acid esters. Enzyme Microb. Technol. 31, 775-783 (2002).

29. Palomo, J.M. et al. Modulation of the enantioselectivity of Candida antarctica B lipase via conformational engineering: kinetic resolution of $( \pm)-\alpha$-hydroxyphenylacetic acid derivatives. Tetrahedron Asymmetry 13, 1337-1345 (2002).

30. Palomo, J.M. et al. Synthesis of enantiomerically pure glycidol via a fully enantioselective lipase-catalyzed resolution. Tetrahedron Asymmetry 16, 869-874 (2005).

31. Fernandez-Lorente, G. et al. Glutaraldehyde crosslinking in the presence of detergents of lipases adsorbed on aminated supports: improving lipases performance. Biomacromolecules 7, 2610-2615 (2006).

32. Palomo, J.M. et al. Modulation of Mucor miehei lipase properties via directed immobilization on different heterofunctional epoxy resins. Hydrolytic resolution of $(R, S)$-2-phenyl-2-butyroylacetic acid. J. Mol. Catal. B Enzymatic 21, 201-210 (2003).

33. Turková, J. Oriented immobilization of biologically active proteins as a tool for revealing protein interactions and function. J. Chromat. B Biomed. Sci. Appl. 722, 11-31 (1999).

34. Penzol, G., Armisen, P., Fernández-Lafuente, R., Rodes, L. \& Guisán, J.M. Use of dextrans as long, inert and hydrophilic spacer arms to improve the performance of immobilized proteins acting on macromolecules. Biotechnol. Bioeng. $\mathbf{6 0}$ 518-523 (1998). 
35. Tardioli, P.W., Fernandez-Lafuente, R., Guisán, J.M. \& Giordano, R.L.C. Design of new immobilized-stabilized carboxypeptidase A derivative for production of aromatic free hydrolysates of proteins. Biotechnol. Prog. 19, 565-574 (2003).

36. Fuentes, M., Mateo, C., Guisán, J.M. \& Fernández-Lafuente, R. Preparation of inert magnetic nano-particles for the directed immobilization of antibodies Biosen. Bioelec. 20, 1380-1387 (2005).

37. Mateo, C. et al. One step purification, covalent immobilization and additional stabilization of poly-His-tagged proteins using novel heterofunctional chelate-epoxy supports. Biotechnol. Bioeng. 76, 269-277 (2001).

38. Pessela, B.C.C. et al. One step purification, covalent immobilization and additional stabilization of a thermophilic poly-His-tagged beta-galactosidase of Thermus sp. strain T2, novel heterofunctional chelate-epoxy supports. Biomacromolecules 4, 107-113 (2003).

39. Abad, J.M. et al. Immobilization of peroxidase glycoprotein on gold electrodes modified with mixed epoxy-boronic acid monolayers. J. Am. Chem. Soc. 124, 12845-12853 (2002).

40. Grazu, V. et al. Solid-phase reducing agents as alternative for reducing disulfide bonds in proteins. Appl. Biochem. Biotechnol. 110, 23-32 (2003).

41. Fernández-Lafuente, R. et al. Preparation of activated supports containing low $\mathrm{pK}$ amino groups. A new tool for protein immobilisation via the carboxyl coupling method. Enzyme Microb. Technol. 15, 546-550 (1993).

42. Hermanson, G.T. Bioconjugate Techniques. (Academic Press Inc., San Diego, CA, 1996).

43. Brocklehurst, K., Carlsson, J., Kierstan, M. \& Crook, E. Covalentchromatography by thiol-disulfide interchange. Methods Enzymol. 34, 531-544 (1973).
44. Nogueira, R., Lämmerhoder, M., Maier, N.M. \& Lindner, W. Spectrophotometric determination of sulphidryl concentration on the surface of thiol-modified chromatographic silica particles using 2,2'-dipyridyl disulfide reagent. Anal. Chim. Acta 533, 179-183 (2005).

45. Grazú, V. et al. Stabilization of enzymes by multipoint immobilization of thiolated proteins on new epoxy-thiol supports. Biotechnol. Bioeng. 90, 597-605 (2005).

46. Hunt, P.D., Tolley, S.P., Ward, R.J., Hill, C.P.y. \& Dodson, G.G. Expression, purification and crystallization of penicillin $\mathrm{G}$ acylase from $E$. coli ATCC11105. Prot. Eng. 3, 635-639 (1990).

47. Montes, T. et al. Genetic modification of the protein surface to improve its reversible enzyme immobilization on ionic exchangers. Appl. Environ. Microb. 73, 312-319 (2007).

48. Fuentes, M. et al. Mixed ion exchange supports as useful ion exchangers for protein purification: purification of penicillin $\mathrm{G}$ acylase from Escherichia coli. Biomacromolecules 8, 703-707 (2007).

49. Fernández-Lafuente, R., Armisén, P., Sabuquillo, P., Fernández-Lorente, G. \& Guisan, J.M. Immobilization of lipases by selective adsorption on hydrophobic supports. Chem. Phys. Lipids 93, 185-197 (1998).

50. Palomo, J.M., Fuentes, M., Fernández-Lorente, G., Mateo, C., Guisan, J.M. \& Fernández-Lafuente, R. General trend of lipase to self-assemble giving bimolecular aggregates greatly modifies the enzyme functionality. Biomacromolecules 4, 1-6 (2003).

51. Palomo, J.M. et al. Use of immobilized lipases for lipase purification via specific lipase-lipase interactions. J. Chromatogr. A. 1038, 267-273 (2004).

52. Palomo, J.M. et al. Lipase-lipase interactions as a new tool to immobilize and modulate the lipase properties. Enzyme Microb. Technol. 36, 447-454 (2005). 